Article

\title{
What Common Agricultural Policy after Brexit?
}

\author{
Christilla Roederer-Rynning ${ }^{1, *}$ and Alan Matthews ${ }^{2}$ \\ ${ }^{1}$ Department of Political Science and Public Management, University of Southern Denmark, 5230 Odense, Denmark; \\ E-Mail: crr@sam.sdu.dk \\ 2 Department of Economics, Trinity College Dublin, 2 Dublin, Ireland; E-Mail: alan.matthews@tcd.ie \\ * Corresponding author
}

Submitted: 27 March 2019 | Accepted: 21 June 2019 | Published: 16 September 2019

\begin{abstract}
Suppose we were in 2028: what would the Common Agricultural Policy (CAP) look like then? Would it be significantly different from the policy we know today? How, and why? And to what extent would Brexit have catalyzed these changes? The CAP is one of the founding policies of the EU and a strategic lever to address critical 21st century challenges such as climate change and the rising demand for food at the global level. It also has an important role in Europe to address the growing urban-rural divide and its potentially destabilizing impact on European politics. In this article, we examine the impact of Brexit from a political-economic perspective emphasizing the multi-level context within which the CAP is embedded. As an EU member state, the UK found a way to partly accommodate the CAP to its needs even though this policy was a source of intense UK dissatisfaction with the EU. Post-Brexit, the budgetary and market implications of the UK's departure may favour positions that support a return to a more traditional policy of farm income support. On the other hand, more radical farm policies in England and Wales could partly offset these effects by setting the agenda for continued CAP reform, if they are seen to be successful.
\end{abstract}

\section{Keywords}

agricultural policy; Brexit; Common Agricultural Policy; European Union; reform; United Kingdom

\section{Issue}

This article is part of the issue "The Impact of Brexit on EU Policies", edited by Ferdi De Ville (Ghent University, Belgium) and Gabriel Siles-Brügge (University of Warwick, UK).

(C) 2019 by the authors; licensee Cogitatio (Lisbon, Portugal). This article is licensed under a Creative Commons Attribution 4.0 International License (CC BY).

\section{Introduction}

There is an irony in reflecting about the impact of Brexit on the Common Agricultural Policy (CAP). Both the CAP and the UK are 'pivotal outliers'. On the one hand, the UK is the powerful but reluctant Member State (De Ville \& Siles-Brügge, 2019)-at once, one of the largest economies in the EU and one of the Member States with the most EU Treaty exemptions. On the other hand, the CAP is an exceptional policy of redistribution, making up a large share of the EU budget in an EU political system operating by default through regulatory intervention; and home to major EU legal and institutional innovations (e.g., comitology and jurisprudence of the European Court of Justice in the 1960s and 1970s). Taken together, these two pivotal outliers arguably embrace one of the most problematic aspects in the evolution of EU policies. Agricultural policy was one of the main reasons why French President de Gaulle twice vetoed a UK membership application, and why the UK fought for a budget rebate. The bones of contention were rooted in the relative unimportance of farming in the UK compared to continental European countries, but also to different approaches to farm support (price guarantees vs payments), Britain's long-standing liberal tradition in trade, and competition from Commonwealth products. Over time, additional sources of tension included the EU budget, from which the UK benefitted little and to which it contributed much, and a range of new concerns, including the environment, animal welfare, and consumer pro- 
tection. Today, freedom from the CAP's 'yoke' has been one of the main withdrawal gains coveted by Brexiteers, hard and soft.

Pursuing this theme of antagonism between two pivotal outliers, we ask: what has British membership meant for the CAP? And how and why might Brexit affect the CAP? A policy in flux since the late 1980 s, the CAP is now in the midst of a new round of reform, taking place in parallel with negotiations on the renewal of the EU's longterm budget framework (the so-called multi-annual financial framework [MFF] 2021-2027). As observers have noted, the history of the CAP shows 'a shift from 'simply' supporting farmers to paying farmers for the delivery of environmental and other non-market goods and services, and towards more general rural development' (Harvey, 2015). The farm income support objective remains the dominant one, although the mechanism of this support has altered over time and is now delivered largely through decoupled direct payments. However, the legitimacy of these direct payments as well as their effectiveness in delivering income support remains contested (Buckwell, 2017; Harvey, 2015). Efforts have been made to justify these payments as compensating farmers for environmental conservation efforts, given the link through cross-compliance and, more recently, the greening payment which absorbs $30 \%$ of the direct payments budget. Additional payments are provided to farmers through the CAP's rural development pillar to farmers who voluntarily agree to adopt practices favourable for the environment and climate stabilization that go beyond these mandatory baselines. However, these measures have failed to reverse the negative environmental consequences of EU farming practices (Pe'er et al., 2017).

Thus, the future direction in which the CAP should go remains a highly contested issue (Mottershead et al., 2018). Faced with the certainty of a significant Brexit budget hole, the Commission proposals both highlight the need for a greater level of environmental and climate ambition in the light of the EU's commitments to the UN Sustainable Development Goals (SDGs) including the Paris Agreement on climate change and target the more environmentally-friendly part of the CAP for budget cuts. Member States have been focused on simplification and the preservation of their 'national envelopes' tied to farm payments. Farm unions and their advocates in the European Parliament's (EP) agriculture committee have insisted on the need to maintain the level of income support and seek stronger market regulation and protection against market crises. In sum, the future of the CAP remains shrouded in ambiguities and contradictions.

What Brexit means for the future of debates around these issues in the CAP remains a largely unexplored question. The sparse literature on this topic highlights the potentially large impact of Brexit for the CAP, mainly owing to the implications of the 'Brexit-sized hole in the EU budget' and the weakening of the liberal-environmental coalition in the Council (EP, 2017; Matthews, 2016). Taking this argument one step further, we examine in this article not only the effects of Brexit that are directly related to the 'withdrawal factor' itself, but also those that are related to the responses and adjustments of EU actors and institutions (De Ville \& Siles-Brügge, 2019). Using this framework, our article shows how changing interactions between the domestic, European, and international arenas have affected opportunities for UK agency in the CAP (Section 2); how the UK exploited these opportunities in the CAP reforms of the last two decades (Section 3); and finally, how the lessons of history can help us to predict how the CAP might respond to Brexit in the future (Section 4).

\section{Three Eras of CAP Governance and Growing Opportunities for UK Revisionism}

What we call the CAP is in fact a patchwork of policies, focusing primarily on the farming component of agriculture, which are tied to multiple arenas of decisionmaking: the domestic arena, the EC-EU arena, and the international arena (Roederer-Rynning, 2019). This multilevel construction has been a source of 'institutional dynamism' (Thelen \& Steinmo, 1992) over time. Following the formative years of the early 1960s, we distinguish three main CAP eras, each characterized by a different mix of domestic-European supranational-and international policy elements. In this section, we briefly present these three eras with a view to outlining the historically changing set of political opportunities for UK CAP revisionism.

CAP 1.0 (1964-1985) corresponds to the era of embedded liberalism. This expression comes from the international political economy literature, where it refers to the postwar economic order that flourished under the umbrella of the multilateral Bretton Woods institutions (Ruggie, 1982; Steinberg, 2006). Embedded liberalism epitomized a balancing act between economic liberalism and social welfare. In European agricultural affairs, this period marked the development and consolidation of a policy regime which was both strongly Europeanized in its policy dimension while deeply rooted in domestic politics (Daugbjerg \& Roederer-Rynning, 2014). It has been argued that the founding negotiations on this first CAP regime were fast-tracked in 1961 in order to reach an agreement before taking position on the first UK application for membership. Thus according to Ackrill (2000, p. 33):

The French did not want to open these [UK accession] negotiations until the CAP had been shaped, as they feared the UK would try to mould the CAP in line with their existing policy of low prices and direct payments to farmers, rather than the 'Continental' high-priced model.

When the UK joined the Community in 1973, the CAP was fully shaped, it was highly protectionist, and it centered on a system of (high) price support. This CAP was a source 
of multiple and intense grievances for the UK, which benefitted little from farm support while contributing a disproportionate share to the EC budget mostly spent on farm support.

CAP 2.0 (1986-2008) marked the internationalization of CAP governance. For the first time, the liberalization of agricultural trade became a top priority of international trade negotiators in the Uruguay round of the General Agreement on Tariffs and Trade (GATT; Daugbjerg \& Swinbank, 2009). This context facilitated the adoption of the MacSharry reform of 1992, which marked the shift from traditional price support to farm payments. With the subsequent Fischler reform of June 2003 and Health Check of the CAP of 2008, these farm payments were further 'decoupled' from output and made conditional upon social, economic, and environmental criteria via the cross-compliance or conditionality of farm payments. Further international pressures for reform resulted from adverse rulings in the World Trade Organization (WTO) dispute settlement process (bananas, sugar) and from the priority of DG Trade under Commissioner Pascal Lamy to provide duty-free quotafree access to the EU market to least-developed countries (sugar, rice). Finally, Agenda 2000 and especially the Fischler reform built an important element of flexible implementation into the CAP. Flexible implementation was later embedded in the Cioloş CAP reform of 2013, through an expanded menu of choices for the implementation of direct payments as well as the 'greening payment' introduced in this reform. Thus, CAP 2.0 offered better opportunities for the UK to push a reform agenda.

The current phase of agricultural policy, CAP 3.0 (2009-now), is marked by a more politicized CAP. Higher world prices following the 2008 world food crisis allowed the EU to pursue a less defensive trade strategy and facilitated the phasing out of export subsidies on EU farm commodities. However, international trade pressures, despite the failure of multilateral trade negotiations, continue to be a constraint because of bilateral trade agreements. European 'sensitive products' like beef, sugar, and poultry have been a sticking point in the current negotiations between the EU and the Mercado Común del Sur (MERCOSUR), composed of Argentina, Brazil, Paraguay, Uruguay. Likewise, the EU has defensive agricultural interests in the bilateral negotiations recently launched with Australia and New Zealand. Besides international trade liberalization, two new sources of politicization have emerged and gained importance since 2009.

The first is the rapid rise of global concern over climate change and the environmental agenda more broadly. The farm and food sector features centrally in the UN SDGs adopted in 2015 and in the Paris Agreement on Climate Change adopted in 2016. The EU has been at the forefront of these efforts, notably with its '2030 Climate and Energy Framework' adopted in 2014, and current proposals on a climate-neutral Europe by 2050 . Public interest in how food is produced has exploded, highlighting issues such as natural resource degradation, biodiversity loss, welfare issues around intensive livestock production and the use of biotechnology. These new priorities and demands for how the CAP budget is spent have fuelled redistributive conflict at a moment when Member States, following the EU enlargement to the Central and East European countries (CEECs), have engaged in an ever more intense competition for EU funding and sought to maintain tight intergovernmental control over the financing of EU policies (Matthews, 2015).

A second source of politicization has been the Treaty of Lisbon, ratified in 2009. The Treaty brought the ordinary legislative procedure to the CAP and abolished the distinction between so-called 'compulsory expenditure'-in practice farm expenditure-lying outside of the purview of the EP and non-compulsory expenditure (where the EP had the last word). The Council of Ministers has thus lost its legal preponderance in agricultural policy and the role of the EP has been strengthened. This 'parliamentarization' has politicized EP-Council relations in agriculture. Since 2009, the two have competed to define the scope of EP powers in the CAP as in the common commercial policy and in the MFF-all of these aspects influencing the CAP and CAP reform. The UK has never been an enthusiastic proponent of the development of EP powers-preferring to stick to the classic method of intergovernmentalism. Although often portrayed as a champion of diffuse interests, the EP played a basically status quo-oriented role in the first CAP reform in 2013 after the ratification of the Treaty of Lisbon (Swinnen, 2015).

Overall, the thrust of the CAP evolution over the last 60 years is to green farm support, push for more trade liberalization, and place more emphasis on sustainability (Roederer-Rynning, in press). For a member state like the UK, championing trade liberalization (De Ville \& Siles-Brügge, 2019) and environmental protection and climate action (Dupont \& Moore, 2019), this has meant better opportunities to shape the CAP to its advantage. How did the UK exploit this context of growing political opportunities?

\section{Putting Membership to Use: From Doléances to Budget Returns}

(Self-)perceptions of UK influence in CAP policy-making have long been shaped by a narrative of liberalism. Still today, the UK distinguishes itself among the large Member States by the 'nearly exclusive emphasis on a neoliberal discourse' (Alons \& Zwaan, 2015, p. 364). Since the 1980 s, British agricultural policy has given 'priority to the free functioning of the market, which plays in favour of the comparative advantage of British agriculture, while it recognizes market failure at valourising externalities' (Garzon, 2006, p. 125). What exactly these 'externalities' are has evolved over time, from an early understanding focused on environmental externalities towards, more 
recently, a more encompassing conception of rural development. Garzon speaks of an 'UK consensus', which is 'at odds with the "continental" vision of multi-functionality": for 'to be acceptable to British policy makers, multifunctionality ought to be focused on environmental outputs and used as a discourse to explain a transition process' (Garzon, 2006, p. 125; see also Delorme, 2004). However, this twofold orientation towards liberalization and greening is not without ambiguities and trade-offs, as evidenced by the nascent debate on a post-Brexit UK agricultural policy. Before we examine the contemporary Brexit debate, we explore in this section how the UK brought this overarching liberal narrative to bear on the CAP while a member of the EU, and what kind of tradeoffs and ambiguities it faced in the promotion of a liberal CAP. We proceed by examining the role of the UK in individual CAP reforms, before briefly extending the analysis to other aspects of UK activism, including national implementation and a longstanding focus on better regulation. We draw on various 'insider' sources (such as Cunha \& Swinbank's 2011 detailed 'insider' account of two decades of CAP reforms; and Garzon's 2006 account), and supplementary secondary and primary sources.

The accession 'cahier de doléances': the UK's early membership was marked by vigorous skirmishes on the CAP. In fact, barely two years after joining the Community, the UK held its first membership referendum, through which 'the UK government wished to change the CAP to its advantage' (Ackrill, 2000, p. 52). Three points stood out in the UK government's accession doléances, which reflected the outlying position of the UK, due to historical reasons, in agricultural matters: 1 ) the UK's 'status as a major importer of food'; 2) UK concerns over the fate of Commonwealth agreements securing food for the UK in exchange for assistance to Commonwealth producers; and 3) the UK's status as a major net contributor to the Community budget, behind Germany (Ackrill, 2000, p. 52). A major implication of this structural mismatch was that UK CAP revisionism was soon channeled outside of the CAP proper: i.e., in the larger intergovernmental budgetary battles, which culminated in a 'UK budget rebate' under Prime Minister Thatcher. The budget compromises of the 1980s had no effects on the CAP's policy design; they perhaps even contributed to sustaining it in a sub-optimal form. The UK nevertheless won two victories in this period: 1) the introduction of the Less Favoured Areas directive in 1975, which allowed it to direct support to its upland farms; and 2) the introduction of agri-environment schemes, initially on a voluntary basis (Regulation [EEC] 797/85). At first, only the UK and Germany made use of this voluntary option, but eventually Agricultural Environment and Climate Measures (AECMs) became a mandatory component of the rural development pillar of the CAP.

The MacSharry reform (1992)-arguably the first and most far-reaching CAP reform-found the UK in a paradoxical position of opposition. Although the UK called for a radical CAP reform in the context of the GATT nego- tiations, it entered the MacSharry reform as the leader of an opposition comprising the Netherlands, Belgium, and Denmark (Cunha \& Swinbank, 2011, p. 33; see also Coleman et al., 1999, cited in Garzon, 2006, p. 67). The most contentious issue was modulation, which in these early years essentially meant capping direct payments as a function of farm size. Fearing the impact of capping for its larger farms, the UK minister explained in the Council that he was 'not prepared to buy a reform at the expense of turning Europe's agriculture into a tourist attraction for people who liked farming in Marie Antoinette style' (Cunha \& Swinbank, 2011, p. 79). The UK also conditioned its approval of CAP reform on guarantees that its financial impact would lie within agreed budget limits (Cunha \& Swinbank, 2011, p. 85). Domestic politics played a big role in shaping the UK's initial position. The UK parliamentary elections were held in the midst of the CAP reform, during which the UK minister expressed his opposition to the MacSharry reform (Cunha \& Swinbank, 2011, pp. 83-84). The strategy of the Commission was to divide the opposition by offering the UK concessions (Cunha \& Swinbank, 2011, pp. 95-96). This strategy was fruitful. After being reelected, the UK minister 'quickly negotiated with the Presidency his conditions to support the reform, and once these had been obtained in a satisfactory way he was the first to leave his allies of yesterday' (Cunha \& Swinbank, 2011, p. 33).

In the Agenda 2000 reform (1999), the multi-issue negotiation package aimed at preparing the EU for the Eastern enlargement, the tables had turned: the UK was now in favor of a CAP reform, together with Denmark and Sweden (Cunha \& Swinbank, 2011, p. 108), eyeing in the enlargement an opportunity to overcome status quo pressures. According to Ackrill (2000, p. 118) these three countries 'felt Agenda 2000 did not go far enough' and wished for more radical reforms. Although the coalitions shifted from issue to issue, the reform was shaped by intense overarching budget discussions, pitting France (against any co-financing of the CAP) against Germany, opposed to any suggestion of drastic price cuts or 'degressivity', i.e., the reduction of direct payments over time. The UK, like France, supported degressivity (Ackrill, 2000, p. 129; Garzon, 2006, p. 84). In line with its longstanding commitment to budget discipline, the UK, together with Austria, Germany, the Netherlands, and France, proposed the principle of 'budget stabilization': thus, 'it would be the finance ministers who decided the financial scope of the CAP reform' (Cunha \& Swinbank, 2011, p. 112). On substantive CAP issues, the UK advocated the termination of dairy quotas, together with Denmark, the Netherlands, and Sweden (Cunha \& Swinbank, 2011, p. 113; Garzon, 2006, p. 84). It also advocated a stronger 'second pillar' of the CAP devoted to rural development (the pillar terminology was introduced in the Agenda 2000), together with Austria, Sweden, Finland, Portugal, and 'more cautiously, France' (see also Ackrill, 2000, p. 129). The UK's approach was that, over time, rural development should replace market support 
and farm payments (Cunha \& Swinbank, 2011, p. 121). Assessments of the reform stress that 'the British government clearly chose the UK rebate over CAP reform' (Cunha \& Swinbank, 2011, p. 118; these authors refer to Serger, 2001, Swinnen, 2008, and Tangermann, 1999). UItimately, the reform introduced 'voluntary modulation', i.e., the possibility for member-states to reallocate a share of their direct payments (pillar one) towards rural development measures (pillar two). Opposition from Germany and Spain explains that modulation remained voluntary. Only the UK and France subsequently used this option. As Garzon (2006, pp. 87-88) notes, 'the United Kingdom...saw this as a way to rebalance the CAP to its advantage'.

In the Fischler reform of 2003, which is often considered to be of a magnitude similar to the MacSharry reform, the biggest change did not come from the UK but from Germany, which had 'transformed itself from an obstructor into a partner of agricultural policy change' (Garzon, 2006, p. 118). The shadow of enlargement loomed large. On the one side, the UK, Sweden, the Netherlands, and Germany feared that extending direct payments to the new Member States would 'perpetuate the costly "compensatory" aid scheme, which they tried to reduce' (Garzon, 2006, p. 98). On the other side, France argued that 'if it was only the CAP that was to be reformed, then this implied that France was paying for enlargement (Greer, 2005, p. 150)' (Cunha \& Swinbank, 2011, p. 135). Germany's realignment, and the continuing pressure to make direct payments WTO-compatible promoted 'a more cohesive bargaining game' (Garzon, 2006), even though the three big Member States continued to favor different options. For the UK, the priority, again, was to avoid a capping of farm payments. The fact that the capping of farm payments played such a prominent role in the UK's position can be surprising given that this position partly contradicts the liberal narrative (large farmers do not need subsidies) and de facto undercut the greening of the CAP by reducing the funding available for environmental and rural development measures. One of the key supporters of this official UK position was the National Farmers' Union (NFU; Delorme, 2004, cited in Garzon, 2006, p. 89; Hennis, 2001; Lowe, Buller, \& Ward, 2002), which was squeezed between the Blair government's lack of interest in agriculture and the rise of the rural development movement. Realizing the lack of popularity of direct payments in the public at large, the NFU 'chose to take part in the discussion [of the Agenda 2000 reform and subsequent reforms], with the support of the Land Owners' Association, in order to influence it, notably by opposing the capping of individual receipts' (Garzon, 2006, p. 89; added emphasis).

In the Health Check of the CAP (2007), the UK advocated a much more radical reform than that envisioned by Agriculture Commissioner Mariann Fischer Boel. Its position was spelled out in a 2005 governmental document authored by the UK Treasury and the Department for Environment, Food, and Agriculture (Her Majesty's
Treasury \& Department of Environment, Food \& Rural Affairs, 2005). This document 'reflected its [UK] traditional liberal standing', advocating for a general retrenchment of public intervention in agriculture except for environmental purposes (Cunha \& Swinbank, 2011, p. 190). This vision had little appeal in the Council although it might have contributed to upgrading the ambition of the Health Check reform (Cunha \& Swinbank, 2011, p. 183).

Remarkably, in the years preceding the second UK referendum over continued membership, consensus remained the norm in the Agriculture Council and the UK had become part and parcel of it (see Table 1). More than two-thirds $(67,7 \%)$ of the decisions were adopted by unanimity or quasi-unanimity (i.e., only one member state abstaining or voting against). Although the CAP had become one of the most contested policy areas in the EU, Council decision-making remained largely consensual even in that area (Hayes-Renshaw, Van Aken, \& Wallace, 2006). The UK was part of the majority in more than $80 \%$ of the cases. While this was lower than France and Italy who were always in the majority, it was the same as Germany, which also voted in support of EU legislation in 26 out of 31 cases in the 2009-2014 period. Even more remarkably, perhaps, the UK did not push back significantly on the last CAP reform before the UK referendum: the Cioloș reform. This reform, adopted in December 2013, was criticized for making too large concessions to conservative agricultural interests, and paying only lip service to the environmental and rural dimension of the CAP. It caused an uproar among environmental NGOs based in the EU and the UK. However, unlike Germany, the UK did not vote against any of the Cioloș reform files.

CAP reform negotiations enable us to assess the UK's role in CAP reform decision-making. While important, this dimension does not exhaust the repertoire of UK activism as a member state. It should be supplemented by a finer analysis of the UK implementation of the CAP. Indeed, the UK has recently used the opportunities offered by flexible implementation to make a partial transition to a new type of agricultural policy. Agricultural policy is devolved in the UK: national implementation of the CAP is undertaken by the agriculture departments of England, Northern Ireland, Scotland, and Wales-under the lead of Defra. Thus, there is no one model of UK implementation. However, the UK as a whole (with the limited exception of Scotland) has distinguished itself by the full decoupling of the single farm payments from 2005 (Greer, 2005). With the Cioloş reform, the UK confirmed its readiness 'to "wear" the new CAP with no transition' (Henke et al., 2018). In addition, while the UK had traditionally paid 'the lowest [rural development] grants and was for many years the only country not to support the continuation of organic production' (Greer, 2005, p. 181), the UK doubled rural development appropriations between 2013 and 2018 (from $€ 2.580$ billion in current prices to $€ 5.195$ billion) by voluntarily modulating farm support during the period. 
Table 1. Council voting results in agriculture (co-decision files), 2009-2014.

Council voting results,
agriculture, 2009-2014 Legislative files (\#) Legislative files (details)

\begin{tabular}{lr}
\hline Voting results: & 31 \\
\hline AT THE EU LEVEL & 17 \\
- unanimity & 4 \\
- unanimity minus one MS & 10 \\
- 20-26 MS support &
\end{tabular}

\section{AT THE UK LEVEL}

- UK in support

- UK abstention

- UK against

\section{6}

1

1

3

2014/0014 (COD): Aid scheme for the supply of fruit and vegetables, bananas and milk in the educational establishments: 25 out of 28 member-states vote in support; Hungary and the Netherlands vote against;

2011/0281 (COD): Common organisation of the markets in agricultural products 2014-2020. Single CMO Regulation: 26 out of 28 member-states vote in support; Germany votes against 2013/0398 (COD): Agricultural products on the internal market and in third countries: information provision and promotion: 25 out of 28 member-states vote in support; the Netherlands and Sweden also vote against

2010/0256 (COD): Outermost regions: specific measures for agriculture: 25 out of 27 member-states vote in support; Sweden also votes against

2008/0183 (COD): Food distribution to the most deprived persons in the Community: 23 out of 27 member-states vote in support; Denmark and Sweden also vote against; and 1 abstains

Note: The data are accessed from the EP Legislative Observatory at https://oeil.secure.europarl.europa.eu/oeil/home/home.do and the Council of the European Union Online Document Register at https://www.consilium.europa.eu/register/en/content/int?typ=ADV.

Lastly, a final aspect in which the UK has sought to change the CAP is through its longstanding commitment to improving regulatory governance. This concern dates back to the late 1980s, with the establishment of a Deregulation Unit under the Thatcher government and was further developed in the Better Regulation agenda in the late 1990s and early 2000s, notably under Tony Blair (Organisation for Economic Co-operation and Development, 2017). In agriculture, the main manifestation of this growing concern was reflected:

- At the domestic level: through a practice of broad and inclusive consultation of stakeholders in discussions of CAP reforms (Cunha \& Swinbank, 2011, p. 147; Greer, 2005, p. 179);

- At the EU level: through the push of the Better Regulation agenda in the CAP, involving rigorous interservice consultations and the systematic use of impact assessments in the bigger CAP reforms, since the reform of the sugar regime which took effect in 2006.

In sum, as an EU member, the UK approached the CAP from an overarching liberal orientation, which delivered a few environmental wins and surprising results, such as the constant battle against the capping of direct payments and the overriding concern for budget rebates. Specific policy victories included the development of measures on less-favored areas and of agrienvironmental schemes. The UK approached the liberalizing MacSharry reform in 1992 from such a posture of opposition that 'one year later, MacSharry was still "disappointed and surprised" with these attacks' (Cunha \& Swinbank, 2011, p. 79). Later, the UK found itself on the side of CAP reform, but often with a hard-nosed focus on budget returns, which produced inconstant coalitions and made substantive CAP reforms almost impossible. While the liberalizing and greening agenda would probably have developed without the UK, the UK nevertheless offered a powerful narrative combining liberalism and environmentalism and striking illustrations of the paradigm at home, and it was a persistent advocate of bringing better regulation to agriculture.

\section{Preparing for Brexit: EU Adjustment Strategies and Narratives}

On 29 March 2017, the UK invoked Article 50 of the Treaty on EU which began the process of its withdrawal from the EU. This initiation of Brexit took place just 
as the Commission began work as part of its 2017 Work Programme on modernization and simplification of the CAP. This led to a Communication published in November 2017 outlining its ideas for the design of the CAP post 2020 and ultimately to legal proposals published in June 2018. However, Brexit has meant that the UK's voice in the AGRIFISH Council and, to a lesser extent, in the Parliament's agricultural committee on the substantive negotiations on the Commission's proposal has been silent. It has effectively opted out of trying to influence the course of the negotiations. Brexit also had an immediate impact on the Commission's preparations for the next MFF which it eventually proposed in May 2018. It means the departure of the second largest net contributor to the EU budget and thus puts pressure on the other Member States either to make savings in existing policies or to contribute more to the future EU budget.

The UK is a major net importer of agri-food products with the bulk of its imports supplied by EU exporters. Brexit raises the prospect of the re-introduction of tariff and non-tariff barriers on trade between the UK and the EU27. The UK market will also become less valuable and more competitive if it adopts its proposed low-tariff regime for agri-food products (NFU, 2019) and allows easier access for third country exporters. This will lead to the displacement of produce previously exported to the UK to the internal EU market, with potentially adverse effects on EU market prices and farm incomes. Finally, the prospect of Brexit has given rise to a vigorous debate within the UK and its constituent countries on the potential shape of post-Brexit agricultural policy. Some UK countries are discussing a major re-orientation of agricultural policy from the traditional emphasis on farm income support to a justification of public support based on the provision of public goods. If such a reorientation were to be successfully implemented in one or more UK countries, it could in turn shift the centre of gravity of future debates on the CAP. In this section, we examine how the EU has responded to these threats and their implications for the future of the CAP.

The impact of Brexit on the EU budget is the one most widely discussed. The UK's departure leaves a gap to be filled, estimated at around $€ 13$ billion annually in the coming MFF period compared to anticipated annual EU budget expenditure of around $€ 170-180$ billion. The gap can be filled either by increased contributions from the remaining Member States or by reducing the current level of spending. The Commission proposal sought additional resources but also proposed savings in existing programmes including both the CAP and cohesion spending. It recommended a nominal cut in CAP spending in the next programming period of between $3-5 \%$ compared to the 2014-2020 MFF, adjusted for the UK's departure, in the context of a modest increase in the overall MFF from $1.00 \%$ to $1.08 \%$ of EU Gross National Income (GNI; $1.11 \%$ when the budgetization of the European Development Fund is considered). This translates into a cut of around
$12 \%$ in real terms (Matthews, 2018). The Commission's priority was to protect the budget for income support (European Agricultural Guarantee Fund, financing Pillar 1 expenditure) in nominal terms. All the nominal reduction will fall on the European Agricultural Fund on Rural Development financing Pillar 2 expenditure, although part of this reduction will be offset by an increase in the share of Member State co-financing of rural development expenditure by 10 percentage points.

This proposed cut in the CAP budget, even if modest enough in nominal terms, has been fiercely opposed by several Member States which have called for an overall increase in the MFF to allow the level of CAP spending to be maintained in real terms (Ministers of Agriculture, 2018). The Parliament has also criticized the Commission proposal and has called for a much larger MFF equal to $1.3 \%$ of EU GNI as well as for maintaining the CAP budget in real terms (EP, 2018). Farm unions have supported this call, arguing that it was crucial 'to make sure that farmers do not end up paying the price of Brexit' (Committee of Professional Agricultural Organisations-General Committee for Agricultural Cooperation in the European Union, 2018). It is not clear if these demands to maintain the CAP budget constant in real terms from the agricultural lobbies will be supported by the Finance Ministries in the Member States. Other Member States have called for the Commission's budget proposal to be even further reduced, including further cuts in CAP spending (Austrian Presidency, 2018). While the controversy over the size of the next MFF and the amount of CAP spending is not all due to Brexit, the UK departure undoubtedly makes agreement on the next MFF in the European Council more difficult.

These negotiations on the post-Brexit MFF run parallel to the debate on the shape of the CAP after 2020. The Commission's proposal is driven partly by a desire to simplify what all agree has become a hugely complex policy to administer. Another driver is the need to modernize the CAP to reflect heightened challenges and new commitments. These include greater market price uncertainty and a more pessimistic market outlook; the need to respond to increased market access under free trade agreements; the need to better harness innovation and advances in digital technologies both to improve the accuracy and efficiency of the implementation and monitoring of CAP instruments as well as their practical application in rural areas; and the need to better meet societal expectations regarding farming and food, including a greater emphasis in CAP spending on environment and climate issues.

The proposal's most innovative element is to move to a new delivery model entailing greater responsibility and flexibility for Member States to design their agricultural policies, albeit still within a common EU framework. Control over Member State interventions would shift from a compliance framework (are payments to farmers in compliance with the rules set at EU level for these payments?) to a performance framework (in which the 
Commission will focus on auditing outcomes based on achieving agreed performance indicators).

In its legal proposal, the Commission has suggested a new 'green architecture' for the CAP. The current system consists of cross-compliance (made up of statutory minimum requirements and a set of minimum standards of good agricultural and environmental practice which all recipients of CAP payments should observe), a greening payment to farmers who observe some simple practices beneficial to the environment and climate, and voluntary AECMs. This will be replaced by a system of enhanced conditionality, a new eco-scheme funded as part of Pillar 1, and voluntary AECMs. Pressure to embed environmental and climate action even more centrally into the CAP has moved up the political agenda because the EU is signed up to, and committed to, action on the Paris Agreement on climate (translated into EU emission reduction goals for 2030 to which agriculture and the land using sectors must contribute) and the UN SDGs. However, the bulk of CAP funding will continue to be allocated to area-based direct payment schemes, albeit the Commission proposes that these should be better targeted on small and medium-sized farms.

The greater emphasis on environmental and climate ambition and flexibility for Member States to better mould agricultural policy interventions to meet their own specific circumstances and needs is closely aligned to UK preferences in successive CAP reforms as argued in Section 3. However, there is no evidence that these proposals are in any way a response to Brexit: the simplification and modernization drivers were already in play. However, the UK's absence from the table as these proposals are negotiated by the co-legislators has weakened the coalition of Member States that support the Commission's objective of a more targeted policy and a greater environmental and climate ambition. At the time of writing (June 2019), there is evidence that the Council and Parliament may well end up watering down some of the more innovative elements in the Commission proposals, although complications due to the realignment of political groups following Parliament elections in May 2019, possible delays in agreeing the next MFF, and potential difficulties in agreeing on the composition of the new Commission, could mean that final decision on the future CAP may be postponed for some years. At the time of writing (June 2019), the UK is scheduled to leave the EU on October 31st 2019. Neither the Parliament nor Council have yet finalised their negotiating positions on the three CAP regulations for the post2020 period and, as noted above, the UK's voice has been largely absent from the debates to formulate these positions. Trilogues may not get under way until after MFF conclusions for the 2012-2027 period are agreed by the European Council, meaning that the UK would no longer have any say in the future CAP after that point. Of course, if there were a further extension of the Brexit process beyond October 31 2019, the votes of the UK in the Council and of UK MEPs in the Parliament could still influence the
CAP outcome if the UK is still a Member State when the votes are finally taken.

Empirical studies of the likely impact of Brexit on EU agricultural markets suggested only a limited impact, particularly if the UK remained in a close economic relationship with the EU, with adverse effects concentrated on a small number of neighbouring Member States and particularly Ireland (Bellora, Emlinger, Fouré, \& Guimbard, 2017). As the prospect of a disorderly Brexit in which the UK leaves the EU without a withdrawal agreement (the 'no-deal' scenario) increased in the first half of 2019, more attention focused on the likely adverse market impacts in such a scenario. The UK has indicated that it intends to introduce a highly liberalized tariff schedule in the event of 'no-deal' including zero tariffs on many agrifood products that are currently protected by the EU's common external tariff (NFU, 2019). This will open up the UK market to easier access by third country exporters. Some tariffs will be maintained for sensitive products such as beef, lamb and some dairy products but these will also be applied to UK-EU trade. The Commission has stepped up its 'no-deal' preparedness and has emphasized the range of market support instruments at its disposal as well as the opportunities under State aid legislation to assist producers in Member States that may be particularly adversely affected. Already in May 2019 a package of support worth $€ 100$ million (of which half will be provided by the EU) was announced for Irish beef producers based on evidence of exceptional market disturbance arising from the prospect of Brexit. If the range of crisis mechanisms is not up to the task, post-Brexit market chaos could well feed into the narrative demanding a return to a more interventionist CAP with greater powers of market management.

Brexit has also dented the EU's efforts to portray itself as the champion of multilateralism in the trade arena at a time when the US commitment appears to be waning. Brexit requires the UK to establish its own schedule of commitments (in terms of tariff bindings, ceilings on trade-distorting domestic support and tariff rate quota access) at the WTO. These are currently part of the EU's commitments. In particular, the joint UK-EU proposal to split access under tariff rate quotas according to historical market shares has met with opposition from exporters, who argue that they are disadvantaged by the division of a unified tariff quota (under which they can switch supplies between markets in line with relative profitability) into two separate quotas, albeit of the same size, where such switching is no longer possible. Affected exporters point out that the EU does not propose to make a similar pro rata reduction in the tariff rate quotas it has opened under bilateral free trade agreements. Brexit could mean that the EU faced an unwanted WTO dispute that, depending on the outcome, could require it to open more generous tariff tate quotas than it has so far planned to do.

In the longer-term, one of the more important impacts of Brexit on the CAP could arise through a 'demon- 
stration effect' if some UK countries decide to pursue their agricultural policy objectives through a radically different set of policy interventions compared to the CAP. All of the four UK countries have launched consultations on future agricultural policy. The UK Government has published an Agriculture Bill that provides the architecture for most of the UK to start to develop their approaches to supporting farm businesses whilst meeting future international trading obligations (Scotland is currently not covered in the Bill because of disagreements about the overall UK approach to repatriating EU powers in devolved areas of competence; Coe \& Downing, 2018). The UK government has committed to deliver the same level of funding as currently received under the CAP (some €4 billion per year) for farm support until the end of the current parliament, expected in 2022.

Agricultural policy was one of the areas in the UK referendum debate where Brexit supporters saw potential gains from 'taking back control' through a less burdensome policy for farmers and reduced agricultural tariffs lowering prices for consumers (Fresh Start Group, 2016). These ideas are reflected in the Agriculture Bill and in the applied tariff schedule that the UK announced in March 2019 it will implement in the event of a 'no-deal' Brexit. This would result in a significant liberalization of import access for agri-food products. The main innovation in the Bill is to give the Secretary of State new powers to provide financial assistance to those managing the land and delivering public benefits such as air and water quality, public access and productivity in England and Wales. To make way for this system, the Bill provides for the phasing out of direct payments over a seven-year period and their 'de-linking' from any requirement to manage agricultural land during this period. These 'de-linked' payments can be made in a lump sum allowing farmers to invest in their business, diversify or retire from farming. The phase out and de-linking of direct payments is not extended to Northern Ireland. This 'public money for public goods' approach to future farm support goes much further than what the Commission has suggested in its legal proposal for the CAP post 2020, even if both jurisdictions are addressing similar policy objectives. If the UK countries do proceed with this transition, whether it is deemed successful or not will have a significant impact on the CAP debate likely to take place in the next round of CAP reform towards the end of the 2020's.

\section{Conclusion}

Brexit takes place amidst intense political contestation of the CAP, with a new round of CAP reform and MFF negotiations pending. Agricultural policy has always been a lightning rod for UK dissatisfaction with the EU, even if our analysis shows that the UK found ways to partly accommodate the policy to its needs. After contesting the premises of the CAP in the 1970s and 1980s, the UK settled for a hard-nosed policy of budgetary returns. Neither contestation nor budgetary returns offered a constructive alternative, which kept the UK in a marginal position and prevented it from exploiting the full potential of a coalition of reform-minded Member States.

The UK leaving the EU opens the possibility that the dynamics around the CAP in future may be different. The Commission's legal proposal for the CAP post 2020 is motivated by new international commitments under the Paris Agreement and the UN SDGs requiring greater environmental and climate ambition, the need to address the growing revolt by Member States and farmers against perceived bureaucracy and overly complex administration, and the recognition that more effort needs to be put into supporting innovation to avoid EU farming falling behind in exploiting the opportunities of digital agriculture. These concerns to a large degree reflect UK interests, although there is no evidence that Brexit influenced or prompted the reform. Nonetheless, the absence of a strong voice from the UK in the Council and EP may weaken the forces supporting the more innovative aspects of Commission's proposal.

The immediate impact of Brexit is the hole it leaves in the EU budget. It remains unclear whether Member States will agree to pay in the additional cash to maintain current levels of CAP spending or whether the more hard-nosed policy of the net contributor countries will prevail. A lower CAP budget is used by those who favour maintaining the traditional focus of the CAP on supporting farm income to argue that farmers cannot afford any increase in the level of environmental obligations. This indirect budget mechanism could be a further way in which Brexit may influence the future shape of the CAP.

Severe market disruption that may follow from a disorderly Brexit in a 'no deal' scenario would also strengthen the hand of those itching to pull the CAP back to a more interventionist policy of market management. On the other hand, the radical ideas to base farm support on a 'public payments for public goods' principle particularly in England and Wales may have a 'pull' effect in the longer run on the future direction of EU agricultural policy if it is seen as a successful reform.

\section{Acknowledgments}

The authors would like to thank the reviewers, the guest editors, Ferdi De Ville and Gabriel Siles-Brügge, and Brendan Moore for their helpful comments on earlier versions of this article.

\section{Conflict of Interests}

The authors declare no conflict of interests.

\section{References}

Ackrill, R. (2000). The common agricultural policy. Sheffield: Sheffield Academic Press.

Alons, G., \& Zwaan, P. (2015). New wine in different bottles: Negotiating and selling the CAP post-2013 Re- 
form. Sociologica Ruralis, 56(3), 349-370.

Austrian Presidency. (2018). Multiannual financial framework (2021-2027): State of play (Note No. 11871/18). Brussels: Austrian Presidency.

Bellora, C., Emlinger, C., Fouré, J., \& Guimbard, H. (2017). Research for AGRI committee: EU-UK agricultural trade: State of play and possible impacts of Brexit. Brussels: European Parliament.

Buckwell, A. (Ed.). (2017). CAP-Thinking out of the box. Brussels: RISE Foundation.

Coe, S., \& Downing, E. (2018). The Agriculture Bill (2017-19) (Briefing Paper Nuo. CBP 8405). London: House of Commons Library.

Committee of Professional Agricultural OrganisationsGeneral Committee for Agricultural Cooperation in the European Union. (2018). Copa and Cogeca call for EU agricultural expenditure to be maintained. Brussels: COPA-COGECA.

Cunha, A., \& Swinbank, A. (2011). An inside view of the CAP reform process: Explaining the MacSharry, Agenda 2000, and Fischler reforms. Oxford: Oxford University Press.

Daugbjerg, C., \& Roederer-Rynning, C. (2014). The EU's common agricultural policy: A case of defensive policy import. In G. Falkner \& P. Müller (Eds.), Policies in a global perspective: Shaping or taking international regimes? (pp. 38-57). Oxon: Routledge.

Daugbjerg, C., \& Swinbank, A. (2009). Ideas, institutions and trade: The WTO and the curious role of EU farm policy in trade liberalization. Oxford: Oxford University Press.

Delorme, H. (2004). La politique agricole au RoyaumeUni: De l'agricole au rural [The agricultural policy of the United-Kingdom]. In H. Delorme (Ed.), La politique agricole commune, anatomie d'une transformation [The common agricultural policy, anatomy of a transformation] (pp. 73-100). Paris: Presses de Sciences Po.

De Ville, F., \& Siles-Brügge, G. (2019). The impact of Brexit on EU policies. Politics and Governance, $7(3)$, 7-18.

Dupont, C., \& Moore, B. (2019). Brexit and the EU in global climate governance. Politics and Governance, 7(3), 51-61.

European Parliament. (2017). Research for AGRI Committee-Implications of 'Brexit' for the EU agri-food sector and the CAP: Budgetary, trade and institutional issues. Brussels: European Parliament.

European Parliament. (2018). Resolution of 14 March 2018 on the next MFF: Preparing the Parliament's position on the MFF Post-2020. Brussels: European Parliament.

Fresh Start Group. (2016). Rewards of Leave 8) A better deal for British farmers. Conservative Home. Retrieved from http://www.conservativehome.com/ platform/2016/06/fresh-start-rewards-of-leave-8a-better-deal-for-british-farmers.html

Garzon, I. (2006). Reforming the Common Agricul- tural Policy: History of a paradigm change. London: Palgrave.

Greer, A. (2005). Agricultural policy in Europe. Manchester: Manchester University Press.

Harvey, D. (2015). What does the history of the Common Agricultural Policy tell us. In J. McMahon \& M. Cardwell (Eds.), Research handbook on EU agriculture law (pp. 3-40). Cheltenham: Edward Elgar Publishing.

Hayes-Renshaw, F., Van Aken, W., \& Wallace, H. (2006). When and why the EU Council of Ministers votes explicitly. Journal of Common Market Studies, 44(1), 161-194.

Henke, R., Benos, T., De Filippis, F., Giua, M., Pierangeli, F., \& Pupo D’Andrea, M. S. (2018). The new Common Agricultural Policy: How do Member States respond to flexibility? Journal of Common Market Studies, 56(2), 403-419.

Hennis, M. (2001). Europeanization and globalization: The missing link. Journal of Common Market Studies, 39(5), 829-850.

Her Majesty's Treasury \& Department of Environment, Food \& Rural Affairs. (2005). A vision for the Common Agricultural Policy. London: Her Majesty's Stationery Office.

Lowe, P., Buller, H., \& Ward, N. (2002). Setting the next agenda? British and French approaches to the second pillar of the Common Agricultural Policy. Journal of Rural Studies, 18(1), 1-17.

Matthews, A. (2015). The multi-annual financial framework and the 2013 CAP reform. In J. Swinnen (Ed.), The political economy of the 2014-2020 Common Agricultural Policy: An imperfect storm (pp. 169-192). London: Rowman and Littlefield.

Matthews, A. (2016). The potential implications of a Brexit for future EU agri-food policies. EuroChoices, 15(2), 17-23.

Matthews, A. (2018). The CAP in the 2021-2027 MFF negotiations. Intereconomics, 53(6), 306-311.

Ministers of Agriculture. (2018). MemorandumFuture MFF-CAP: Ministers of agriculture from Finland, France, Greece, Ireland, Portugal, Spain. Retrieved from https://www.agriculture.gov.ie/ media/migration/farmingschemesandpayments/ commonagriculturalpolicycappost2020/ MemorandumFutureMFFCAP060618.pdf

Mottershead, D., Hart, K., Maréchal, A., Meredith, S., Lorant, A., Bas-Defossez, F., . . Matthews, A. (2018). Research for AGRI Committee-Towards the CAP post 2020-Appraisal of the EC Communication on 'The Future of Food and Farming' of 29 November 2017. Brussels: European Parliament and Policy Department for Structural and Cohesion Policies.

National Farmers' Union. (2019). UK applied Tariff Policy in event of no deal Brexit. Brussels: European Parliament and Policy Department for Structural and Cohesion Policies. Retrieved from https://www. nfuonline.com/nfu-online/brexit/uk-applied-tariffpolicy-in-event-of-no-deal-brexi 
Organisation for Economic Co-operation and Development. (2017). Improving regulatory governance: Trends, practices, and the way forward. Paris: OECD Publishing.

Pe'er, G., Lakner, S., Müller, R., Passoni, G., Bontzorlos, V., Clough, D., . . Bonn, A. (2017). Is the CAP fit for purpose? An evidence-based fitness-check assessment. Leipzig: German Centre for Integrative Biodiversity Research (iDiv) Halle-Jena-Leipzig.

Roederer-Rynning, C. (in press). The Common Agricultural Policy: The fortress challenged. In H. Wallace, M. Pollack, A. Young, \& C. Roederer-Rynning (Eds.), Policy-Making in the European Union. Oxford: Oxford University Press.

Roederer-Rynning, C. (2019). The Common Agricultural Policy: A case of embedded liberalism. In Oxford encyclopedia of European Union politics. Oxford: Oxford University Press.

Ruggie, J. G. (1982). International regimes, transactions, and change: Embedded liberalism in the postwar economic order. International Organization, 36(2), $379-415$.

Serger, S. S. (2001). Negotiating CAP reform in the European Union: Agenda 2000 (Report No. 2001: 4).
Lund: Swedish Institute for Food and Agricultural Economics.

Steinberg, R. (2006). The transformation of European Trading states. In E. J. Levy (Ed.), The state after statism (pp. 340-366). Cambridge, MA: Harvard University Press.

Swinnen, J. F. M. (2008). The political economy of the Fischler reforms of the EU's Common Agricultural Policy. The perfect storm? In J. F. M. Swinnen (Ed.), The perfect storm? The political economy of the Fischler reforms of the Common Agricultural Policy (pp. 135-166). Brussels: Centre for European Policy Studies.

Swinnen, J. F. M. (2015). The political economy of the 2014-2020 Common Agricultural Policy: An imperfect storm. Brussels and London: Centre for European Policy Studies and Rowman and Littlefield International.

Tangermann, S. (1999). Agenda 2000: Tactics, diversion and frustration. Agra Europe, 28, A1-A4).

Thelen, K., \& Steinmo, S. (1992). Historical institutionalism in comparative politics. In S. Steinmo, K. Thelen, \& F. Longstret (Eds.), Structuring politics (pp. 1-32). Cambridge: Cambridge University Press.

\section{About the Authors}

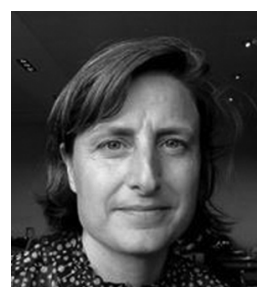

Christilla Roederer-Rynning is a Professor with special responsibilities in Comparative European Politics. She works on EU lawmaking, the Common Agricultural Policy, and trade policy. She coordinated 'The Parliamentarization of EU Politics', financed by the Danish Council for Independent Research. She co-edits Policy-making in the European Union 8th edition, with Helen Wallace, Mark Pollack, and Alasdair Young (Oxford University Press).

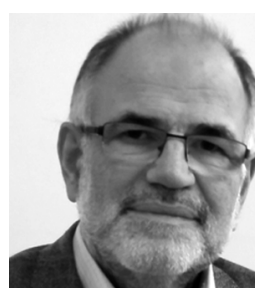

Alan Matthews is Professor Emeritus of European Agricultural Policy at Trinity College, Dublin, Ireland. $\mathrm{He}$ is a former President of the European Association of Agricultural Economists and is currently a member of Ireland's Climate Change Advisory Council. His research interests are in the areas of agricultural policy and international trade policy, including their implications for development and food security. He is a regular contributor to the blog capreform.eu on issues relating to the EU's Common Agricultural Policy. 